\title{
Public Administration on the Financial Market in the Czech Republic
}

\author{
Michal Janovec*
}

* JUDr. Michal Janovec, PhD, Assistant Professor at the Department of Financial Law and Economics at the Faculty of Law, Masaryk University Brno. (e-mail: michal.janovec@law.muni.cz)

\begin{abstract}
This article is dealing with licencing of the financial institutions on the financial market. Licence procedure is a special administrative procedure dealing with systemic important institutions - banks. Good public administration in this area is a basic prerequisite for stabile financial market, because only those institutions proven to be good and stable enough might pass through the difficult administrative procedure, which is licencing procedure. This article aims to confirm or refute the hypothesis that a proper and consistent procedure of taking away licences supports the general objective of regulation and supervision, namely the maintenance of financial market stability.
\end{abstract}

Keywords: public procedure; administrative procedure; licence; bank; liquidation; bankruptcy

\section{Introduction - Granting and Taking Away Licences and Permits on the Financial Market}

It is clearly believed that one of the most important parts of financial market regulation and supervision is the stipulation of conditions on which one may gain access to the financial market as a financial market entity with subsequent monitoring ensuring that the conditions are met and business is conducted in the proper way. These are macro-prudential rules stipulated for the entire financial market - if one wants to become a financial market entity, a licence (banks) or a permit (all the other financial market entities) must be gained. It is far beyond the scope of the present paper to analyse the licencing procedure for all financial institutions so only two are discussed here: banks and securities traders, arguably the second most important financial market entity after banks.

This article aims to confirm or refute the hypothesis that a proper and consistent procedure of taking away licences supports the general objective of regulation and supervision, namely the maintenance of financial market stability. The hypothesis only applies to the termination of financial market entities because when licences are being granted, it is crystal clear that a proper procedure observing all the conditions necessary for the licence to be granted helps to maintain financial market stability.

There are two reasons why only two entities (banks and securities traders) are discussed here in connection with licences and permits. Firstly, the two are undoubtedly the most important institutions conducting business in the financial market (especially banks and their conduct is essential for the stability of the entire system). Secondly, legal norms linked with these entities are rather specific (this is especially true of banks) and they thus illustrate the issue very well. 
Taking away licences and permits is further analysed here on a more general level, i.e. in connection with all financial institutions, and not just banks and securities traders. This is justified by the fact that the end of licences and permits is more or less the same (barring a few irregularities), regardless of which financial institution's licence or permit is cancelled.

\section{Licencing Procedure for Banks}

If anybody wants to offer banking services (i.e. conduct business as a bank in the Czech Republic), there are two options according to Act no. 21/1992 Coll., on banks (hereinafter the Banks Act).

1. The first option is to gain a banking licence from the Czech National Bank (hereinafter $\mathrm{CNB}$ ) or a permit to offer banking services, i.e. accept deposits from the public and offer credit.

2. The second option is to offer banking services in the Czech Republic by banks whose headquarters is in another EU member country by means of a branch as a result of the so-called single licence in the banking market; two conditions are necessary: the foreign bank must own a valid licence from the country of its headquarters and it must follow the procedure stipulated by EU law.

In accordance with the international contract, the CNB can issue a directive raising the number of countries whose banks have the same advantages while doing business in the Czech Republic as banks that are from EU countries. Whoever conducts business under the single licence in another country, is supervised by the domestic supervisory body, with the exception of a few clearly-defined legal norms of the home country. If a bank wants to offer services via its branch, it must go through the so-called notification procedure, in which it presents information regarding its business plan, its list of services, its headquarters, its organisational structure, and its head. These branches only need to comply with the registering obligation of taxable entities stipulated in a special legal norm. ${ }^{1}$ Banks with the headquarters in EU member countries are entitled to conduct business even without setting up a branch if their business is not permanent.

However, this paper only goes on to discuss the granting of a banking licence (hereinafter licence) in a licensing procedure - when a new banking institution under the supervision of the CNB is established.

The licence application (the required form) is submitted to the CNB along with a proposal of the association articles. The minimum capital for would-be banks is CZK $500,000,000$, and this is also the required minimum amount of money gathered by deposits on a pre-arranged account. The licence requirements are stipulated by the CNB directive no. 233/2009 Coll. The application must be submitted in writing and it must include basic information about the applicant, the reason(s) for the application, the objective of the bank, a business plan and a market analysis, plus a number of other documents. All of these are considered in the licensing procedure. 
The licensing procedure formally begins when the CNB informs the applicant that the procedure has commenced. This is, of course, only possible once the application form has been submitted. Along with the commencement of the licensing procedure, the CNB asks the applicant to comment on/make a complaint about the documents submitted in the application form or the method of their assessment. Typically, the licensing procedure lasts 6 months unless it is interrupted because the CNB requires supplementary information. In such a case, the licensing procedure can last up to 12 months. The CNB assesses especially the capacity of the main shareholders regarding their financial stability and power, but it also looks into the level of expertise and the moral standards of persons proposed to form the statutory and executive boards of the bank. Moreover, technical and organisational equipment necessary for the services to be offered is examined, as well as the feasibility of the economic plans for the future liquidity and profitability of the bank. The applicant must pay an administrative fee of CZK 200,000. ${ }^{2}$

Provided that all the necessary conditions are met, the CNB grants the licence. Typically, the category of administrative discretion is applied here because while some aspects and conditions affecting the decision to grant the licence may be objective, others appear rather subjective and their assessment is thus left to the discretion of the assessor. For instance, in some cases it might be disputable whether a given person reaches the required level of expertise or moral behaviour, or whether the technical background is appropriate enough for the type and range of services that the banking institution plans to offer. In order to prevent such unclear situations that may result from some rather vague categories, the $\mathrm{CNB}$ issues official notices that provide more information about the categories and they specify the requirements that applicants should meet. The assessment of such categories as expertise or credibility is thus hopefully clearer and more predictable. ${ }^{3}$

If the application is successful, the licence is given for an indefinite period. The licence stipulates the activities that the bank is allowed to perform; alternatively, it provides a list of conditions that must be met before another type of activity is initiated or that must be observed during the performance of this activity. Some activities present in the licence may be conditioned by the granting of a special permit (e.g. a permit for services in the investment industry which is granted under Act no. 256/2004 Coll., Capital Market Undertakings Act).

In a nutshell, before a bank comes into existence, there must first be a joint-stock company which, sooner or later, manages to meet the requirements of the Banks Act; only after the company has been granted a banking licence, can the company call itself a bank. ${ }^{4}$ The purpose of business activities listed in the List of Company Registers is banking services or all the services that the applicant is entitled to perform according to the licence.

If the CNB's decision is negative, the applicant may file a remonstrance, which is a regular remedial measure present in the administrative order; the decision (which is irrevocable) is then made by the Bank Board of the CNB. The remonstrance, however, has no suspensory effect and the provision about the possible conclusion of the remonstrance proceeding cannot be applied.5 


\section{Granting Permits According to the Banks Act}

In a number of cases the Banks Act demands that banks, prior to making a certain step, ask for permission or inform the CNB of what they are going to do. A prior permission is required in the following cases:

1. a person intends to obtain direct or indirect share of the bank worth at least $20 \%$, $30 \%$, or $50 \%$ of the voting rights of the bank, including a person who wants to reach the above-mentioned limits of the basic capital of the bank, including a person who will become an executive member due to a contract to control the bank - this obligation also applies to persons acting in compliance, ${ }^{6}$

2. prior to a contract about the sale of the bank ort its part,

3. prior to a bank merger, a division of a bank, or a transfer of funds to another bank as a shareholder, ${ }^{8}$

4. when a decision to terminate a bank is reached at the level of the general meeting or when the decision affects the activities which can only be performed by a licence holder, ${ }^{9}$

5. when the basic capital is reduced, unless it is a case of loss compensation, ${ }^{10}$

6. when an auditor is about to be chosen. ${ }^{11}$

Within two days after receiving the application, the CNB must confirm in writing its acceptance, and it must inform the applicant of the deadline by which the CNB must reach a decision. The $\mathrm{CNB}$ must do so no later than 60 working days after sending the confirmation notice. If this deadline is missed, the applicant can act as if the licence has been granted.

It should be stressed, though, that if there is an increase in the qualified interest in the bank or if there is a takeover without the consent of the CNB, this does not mean that such a legal act is automatically nullified. Yet, the voting rights linked with this act cannot be exercised until the permission from the CNB is granted. Legal acts and resolutions of the general meeting made without a prior consent are invalid.

The participant in the prior consent proceeding is only the requesting bank; in the following cases it is also the second contractual party: when the bank or its part is transferred according to letter b), or when there is a bank merger or a bank division, or the funds are received according to letter $\mathrm{c}) .^{12}$

The notification duty is applicable in the following cases:

1. the reduction of the direct or indirect share of the bank under $20 \%, 30 \%$, or $50 \%$ of the voting rights - this duty also applies to persons acting in compliance; after the Banks Act amendment, the duty also applies when the share in the basic capital is reduced below the above-mentioned limits or when there is a loss of control over the bank; further, if there is a proposal to transfer such an amount of share or other rights that constitutes qualified interest in the bank, ${ }^{13}$

2. a change in the association articles, ${ }^{14}$

3. a change of personnel in the statutory body of the bank or in the executive board, ${ }^{15}$ 
4. an intent to open a branch abroad ${ }^{16}$ - having received the notification about the branch abroad, the CNB decides in an administrative proceeding whether the conditions stipulated by EU law are met (according to Article $5 c-5 \mathrm{~m}$ of the Banks Act $)^{17}$ and if the decision is negative (the conditions are not met), it is reviewable in court,

5. the acquisition of qualified interest of another legal person. ${ }^{18}$

\section{Licensing Procedure for Securities Traders}

The establishment and conduct of business of securities traders is governed by Act no. 256/2004 Coll., the Capital Market Undertakings Act (hereinafter CMUA). Before the application is submitted, it is necessary for the applicant to clarify its business intent since it is a key aspect in determining the line of business, particularly as regards the scope of investment services. This also determines the minimum capital requirements, the capital adequacy requirements and other material, personnel and organisational requirements.

The only participant in a permit procedure is a joint-stock shareholder or a limited liability company with its headquarters in the Czech Republic; the application must be submitted in the form prescribed by the CNB including all the compulsory supplements. The application can be submitted by a company even before the company is listed in the List of Company Registers, but it must meet all the criteria required for the permit before its entry in the List - the company must be able to prove them in a trustworthy manner. During the permit procedure it is possible to order a hearing in which the CNB officers specify what additional information is needed to complete an imperfect application. The CNB decides whether the permit is granted or not within 6 months from the day it received the application, unless there have been delays caused by an incomplete or imperfect form. This deadline became stipulated by law in accordance with the MiFID Directive.

In case an existing securities trader plans to make a change in their scope of business, there needs to be a new permit procedure, which is, to a certain extent, similar to the original procedure. The CNB must assess all the lawful requirements as when a new permit is about to be granted; though in this procedure the applicant only provides that information which is relevant for the change in question. Of course, the applicant may refer to the documents that have been submitted in the past three years, providing the relevant data have not changed.

The application seeking to gain a permit or a permit expansion (including all the relevant documents) is purely the responsibility of the applicant and the CNB is in no way obliged to look for documents that are necessary for the applicant to meet the legal requirements.

The administrative fee, payable before or along with the application, is CZK 100,000 ${ }^{19}$ for a permit, or CZK 10,000 for a permit extension. If the fee is not paid, the CNB informs the applicant and sets an extended deadline; if even this deadline is missed, the CNB terminates the administrative procedure.

It is interesting to note that along with a permit application (or even later), the applicant may apply for the registration of another business activity (i.e. other than investment services). 
Such a registration is for free and it is not decided in an administrative procedure. ${ }^{20}$ If the conditions linked with this business activity are met (i.e. they do not prevent the offer of investment services and they do not prevent efficient supervision of the securities trader), the CNB registers the activity and issues a registration notification. ${ }^{21}$ This registration certifies that the conditions stipulated by law have been met. Yet, such a registration can modify itself into an administrative procedure, if the applicant fails to give evidence that the lawful conditions have been met - the CNB then initiates an administrative procedure with the applicant and cancels the registration application providing the applicant does not meet the criteria even during the administrative procedure.

\section{Taking Away Licences and Permits of Financial Market Entities}

Miroslav Singer, the former CNB governor, asserted ${ }^{22}$ that by close of observation of liquidation rules the $\mathrm{CNB}$ helps to increase the transparency of the financial market for its participants, which is why I deem it apposite to include the matter of taking away licences and permits in this article. I attempt to analyse what happens when a financial institution is being liquidated or when it is declared insolvent; in other words, when preventive measures and lawful requirements aiming to prevent the bankruptcy of financial institutions fail.

The licence to conduct business in the financial market is revoked in the following ways:

1. revocation of a licence or a permit as a sanction,

2. revocation of a licence or a permit at the request of a financial market entity,

3. revocation of a licence or a permit resulting from the decision of a financial market entity to close down,

4. revocation of a licence or a permit resulting from the decision of a financial market entity to terminate the activities for which the licence or the permit is needed,

5. revocation of a licence or a permit after it has expired.

Once the licence or the permit has been revoked, the institution enters liquidation unless it enters a different type of market where the licence (permit) is not required; alternatively, an insolvency proceeding may also be initiated.

\section{A Company in Liquidation}

Generally, liquidation of a legal person is treated in Act no. 89/2012 Coll., the Civil Code (hereinafter the CC), which states that the primary objective of liquidation is to settle and distribute the property of the legal person, to settle its debts to creditors and lawfully dispose of the property that remains after liquidation. ${ }^{23}$ The ultimate objective of liquidation is the expungement of the institution from the Commercial Register. A legal person enters liquidation the day it is cancelled or declared invalid. Once the legal person has entered liquidation, the liquidator, without unnecessary delay, makes an entry about it in the public register. ${ }^{24}$ 
As far as the liquidation of a financial institution is concerned, the crucial thing is the appointment of a liquidator. There are only a few particularities in comparison with general legal norms. Natural or legal persons can become potential liquidators for all financial institutions apart from banks, where the liquidator must only be a natural person. ${ }^{25}$ Such a provision is motivated by the unquestionable importance of banks and the extremely high level of responsibility that their liquidation entails - a natural person is liable for unprofessional conduct with all their property as collateral. What is important is the fact that the liquidator is appointed or removed by the court, which follows the proposal of the $\mathrm{CNB}$ - the court has 24 hours to announce its decision. ${ }^{26}$ The CNB plays a prominent role in the process of liquidation since it is not only a supervisory authority - it actually also determines who will be appointed or removed as the liquidator (the court is the institution ultimately responsible for the decision but it always follows the proposal from the CNB). Furthermore, the CNB also determines the liquidator's remuneration, which is paid from the property of the liquidated institution. If the property does not cover the total remuneration, it is covered by the state. The liquidator is obliged to act with due managerial care, ${ }^{27}$ hence their liability for any damage; an exception is the liquidator of an investment company or an investment fund -they must act with professional care. ${ }^{28}$ The liquidator's obligation to act with due managerial care can be inferred from Article 159, par. 1 of the Civil Code, which maintains that whoever "accepts the office of a member of an elected body undertakes to discharge the office with the necessary loyalty as well as the necessary knowledge and care. A person who is unable to act with due managerial care although he must have become aware thereof upon accepting or in the discharge of the office and fails to draw conclusions for himself is presumed to act with negligence". 29

What is the difference between the two notions? Professional care is generally perceived to entail a higher level of expertise, higher requirements and, inevitably, a higher amount of liability for a breach of the professional care rule. If the rule is violated, it is a case of an administrative offence with all the administrative and legal consequences (administrative punishment) with the CNB acting as the administrative body. If the due managerial care rule is violated, the consequences are only in the area of civil procedure - the given institution can only demand a loss compensation via a lawsuit. With the exception of the liquidator of investment companies and investment funds, the CNB does not currently have the power to sanction liquidators who fail to adhere to the rules.

As for the liquidators of financial institutions, the CNB chooses them from persons who are on a special list of trustees in bankruptcy; these persons have passed a specific exam for trustees and they are expected to possess a high level of expertise in this area. The same requirements that apply to the choice of trustees in bankruptcy also apply to the choice of liquidators, which seems wholly logical.

Once it is known who the liquidator is going to be, the CNB submits a proposal of their appointment to the relevant Commercial Court in charge of the Commercial Register. The court then officially appoints the liquidator and the appointment comes into effect the moment it is disclosed either on the official noticeboard of the court or on its electronic noticeboard. When this happens, the liquidator acquires the competence of a statutory body and one of their main duties is to announce in the Official Business Journal that the institution has entered liquidation. The announcement also contains an 
appeal to potential creditors of the institution to submit their claims. The deadline for the creditors cannot be shorter than three months. ${ }^{30} \mathrm{~A}$ problem may arise if there are more creditors than previously expected and the financial situation of the institution reveals that there is, in fact, no other option but to initiate an insolvency proceeding of the financial institution. In my opinion, it is reasonable not to conclude the process of finding out creditors too soon, and the insolvency proceeding submission should also be considered carefully. The reason is that liquidation is closely supervised by the CNB (the CNB can even remove the liquidator, i.e. it submits such a proposal and nominates another liquidator). In contrast, an insolvency proceeding is not supervised to the same extent because the CNB can only demand information from the trustee in bankruptcy; this, however, is not even enforceable. I am convinced that liquidation is fairer, more carefully controlled and more transparent because of the CNB's intervention and because of the requirements placed on liquidators.

\section{Insolvency Proceeding of Financial Institutions}

There are several substantial differences that apply to financial institutions in insolvency proceedings compared to other entities. Financial institutions are not even subject to the same legislation; or rather, the type of insolvency proceeding is determined by the fact whether it concerns a credit institution or not. It is worth highlighting that unlike in a typical list of financial institutions, Act no. 182/2006 Coll., the Insolvency Act, as amended, states that a financial institution is a bank, a savings or credit bank, an insurance company or a reinsurance company. ${ }^{31}$ The bankruptcy of financial institutions is dealt with in the Insolvency Act (Article 2, section IV), which explicates the differences in comparison with a regular bankruptcy. While there are, admittedly, certain differences between banks and (re)insurance companies, these seem to be rather minute and I thus treat the insolvency of all financial institutions as one group here.

A big difference from the usual insolvency proceeding under the Insolvency Act, is the fact that for financial institutions the trustee in bankruptcy may only be a trustee with a special permit. ${ }^{32}$

What has been mentioned so far clearly suggests that there are, as a matter of fact, two schemes of bankruptcy. On the one hand, there are financial (credit) institutions, on the other hand, there are other institutions such as securities traders, investment companies, investment funds, pension companies and pension funds. If these non-credit institutions go bankrupt, they are dealt with in the regular bankruptcy scheme. It is not even necessary that their licence or permit be revoked; unlike with financial institutions where licence revocation is a prerequisite for the application of the Insolvency Act.

What is then the main difference between the two schemes? Apart from the abovementioned necessity to revoke the licence before an insolvency proceeding may begin, it is also people who can submit the insolvency proposal - for financial institutions, the proposal may be submitted by, except for creditors and debtors, the CNB, as well. Another unique option is a solution via liquidation. Yet another important option is the announcement of the crucial parts of the insolvency decision in the Official Journal of 
the European Union, as well as the fact that the claims of creditors resulting from the accounting of the debtor are registered automatically, of which the creditor is informed by the trustee in bankruptcy within 60 days of the company going into liquidation.

These exceptions are quite logical and straightforward. As the CNB supervises these institutions and it has a large amount of highly relevant information about them, it is desirable that it should have the right to lodge an insolvency proposal. It is also wholly logical to include automatically all the creditors present in the accounting because the insolvency of a financial institution is always of such a scope and magnitude that one cannot expect all the creditors to be informed of the insolvency and to submit their claims; this is especially true of foreign creditors. This would also undoubtedly result in an immense administrative overload for the trustee in bankruptcy and the insolvency court - it would be neigh impossible to process such a vast number of documents. Naturally, problems may arise if the accounting is badly kept or even missing - this means a considerable load for the trustee in bankruptcy that must do their best to obtain the relevant information. If the information is still unavailable, there is no other option but to include those creditors that have been found out - either from the accounting or by means of applications submitted after the announcement in the Official Journal of the European Union.

I have suggested above that liquidation is more favourable for creditors than bankruptcy. What happens, though, if, theoretically speaking, these two clash? The CNB may revoke a licence or a permit and suggest a liquidation entry while submitting a proposal to the relevant Commercial Court with a proposal as to who the liquidator should be. The court has 24 hours to decide and in this interval a debtor or a creditor may submit an insolvency proceeding proposal. The insolvency proceeding commences the day the proposal physically appears at the court. ${ }^{33}$ The insolvency proceeding is thus opened and, a few hours later, the court opens liquidation and appoints a liquidator. Thus, the two clash and the institution is both insolvent and in liquidation. Insolvency is, of course, stronger and the court must deal with the insolvency proposal and possibly declare a bankruptcy. If the court dismisses bankruptcy, the insolvency proceeding is cancelled and liquidation may go on. However, if the insolvency proposal is justified, then the institution is declared insolvent and liquidation is put on the back burner - the role of the liquidator is purely formal. I believe that liquidation is beneficial for all the parties involved. One of the reasons why I think so is the fact that if the decision is based on a proposal made by such an institution as the $\mathrm{CNB}$, then there should be no problem with loss compensation. One may assume that if the $\mathrm{CNB}$ proposes liquidation, it knows very well why, and it is then up to the liquidator and his integrity to submit an insolvency proposal if need be. Of course, there is still the court that assesses whether all the requirements for declaring bankruptcy have been met; if the court decides so and the requirements have actually not been fulfilled (i.e. it would have been possible to deal with the situation by means of liquidation), then the state must compensate the loss. 


\section{Conclusions}

The CNB performs the role of an administrative body as far as investment and banking services are concerned; a bank that also wants to offer investment services according to the Capital Market Undertakings Act, can thus submit only one application and the CNB only makes one decision - if it is a positive one, it enables the bank to offer the services. Banks present in the Czech banking market take part in other financial services by means of creating financial groups that might include, for example, an insurance company, a pension fund, an investment company, an investment fund, a financial leasing company, a factoring company, etc.; the CNB carries out supervision over the whole group. The dangers that a bank faces may be caused by its presence in the financial group. That is why some rules of prudential business (especially the capital adequacy, the commitment, and the inner control system) are applied to the group as a whole.

It may be concluded that it is a correct decision to entrust a single body with administrative procedures permitting an activity or granting a licence, as well as subsequent supervision of financial institutions owing to the fact that financial services are globalised to such an extent that many financial institutions are active in a number of financial areas. If supervision were carried out separately (including the granting of licences and permits), it would take more time and there would be a greater danger of imperfections because the administrative bodies would have to share information and the decision-making process would be more complicated and time-consuming. This is hardly acceptable these days.

As regards the termination of business activities, it is clear that the current legislation (based on EU law) considers liquidation and insolvency of financial institutions a serious issue; it is, after all, to everyone's benefit to make sure that these proceedings affect the stability of the economic system as little as possible. Except for the specific issues of liquidation and insolvency, there are also buffers such as the Deposit Insurance Fund and the Financial Market Guarantee System, which provide a certain form of guarantee that deposits or other entrusted finance will be paid out should financial institutions be declared insolvent.

In case there is a potential clash between liquidation and insolvency, I am convinced that liquidation should be given preference (the reasons are outlined above); all the more so because, occasionally, insolvency proposals are submitted without a proper reason. I also believe that the liquidator, carefully chosen by the $\mathrm{CNB}$, provides a sufficient guarantee of an objective assessment of the debtor's financial situation - the insolvency proposal will be filed if the conditions stipulated by law are met.

I can certainly confirm the hypothesis set at the beginning of this article, namely that the right and consistent method of terminating the activities of financial institutions supports the general objective of regulation and supervision: the maintenance of financial market stability. Public administration in this area is without any doubt one of the tools which supports the financial market stability when good administration is applied. It is evident that without clear rules and their consistent application the financial market can barely be kept transparent. If there were any doubt surrounding the end of a financial institution (whether it be an enforced or a voluntary decision) by means of liquidation or insolvency, financial institutions would be left in relative uncertainty as to how to conduct 
business in the financial market. Without realising and accepting the negative consequences of improper conduct of business activities (e.g. taking excessive risk without sufficient safety measures), financial institutions might find it difficult to avoid such conduct that could result in terminating their business. 


\section{References}

1 Cf. $\$ 33$, Act no. 337/1992 Coll., on tax and fees administration, as amended.

2 Item. 65/1, letter a) of Act no. 634/2004 Coll., on administrative fees, as amended.

3 Based on the CNB Official Notice, issued on the $3^{\text {rd }}$ of December 2013, explaining the notions of credibility and expertise.

4 Cf. Article 3, par. 1 of the Banks Act.

5 Cf. Article 152 par. 5 Act no. 500/2004 Coll., the administrative order.

6 Cf. Article 20 par. 3 of the Banks Act.

7 Cf. Article 16 par. 1 letter a) of the Banks Act.

8 Cf. Article 16 par. 1 letter c) of the Banks Act.

9 Cf. Article 16 par. 1 letter b) of the Banks Act.

10 Cf. Article 16 par. 1 letter d) of the Banks Act.

11 Cf. Article 22 par. 4 of the Banks Act.

12 Cf. Article 16 par. 1 of the Banks Act.

13 Cf. Article 20 par. 14 of the Banks Act.

14 Cf. Article 16 par. 2 letter a) of the Banks Act.

15 Cf. Article 16 par. 2 letter b) of the Banks Act.

16 Cf. Article 16a par. 1 of the Banks Act.

17 It is a provision connected with the principle of a single licence, i.e. the possibility to provide banking services in the member countries of the EU, without the need to acquire the licence in every single one of them.

18 Cf. Article 16 par. 2 letter c) of the Banks Act.

19 Item 65/2 letter b) of the Tariff of Administrative Fees, amendment to Act no. 634/2004 Coll., on administrative fees, as amended.

20 Registration in the administrative procedure does not follow part two of the administrative code, but it follows part four (Articles 154 to 158); more specifically it is a different act according to Article 158 of the administrative code.

21 If the trader's activity which should be registered involves a direct link to their own property (Article 8a, par. 1 to 3 of the CMUA), the CNB dismisses the application unless there are extraordinary circumstances (Article 6a, par. 6 of the CMUA).

22 Miroslav Singer, Dobled nad finaninnim trhem [Supervision over the Financial Market], 40. Paper delivered at Den otevřených dveři of the CNB, Prague 12 June 2010.

23 Cf. Article 187 and the following of Act no. 89/2012 Coll., the Civil Code.

24 René Kurka, Anežka Paříková, Subjekty finančního trhu, Vybrané aspekty likvidace a insolvence [Subjects of the Financial Market. Selected Aspects of Liquidation and Insolvency], 60 (Praha, C. H. Beck, 2014).

25 Cf. Article 8 par. 9, of the Banks Act.

26 Cf. e.g. Article 36 par. 1, of the Banks Act.

27 It can be inferred from Article 159 par. 1, of the CC.

28 Cf. Article 348 Act no. 240/2013 Coll., on investment companies and investment funds, as amended.

29 Kurka, Paříková, supra n. 24, at 62.

30 Cf. Article 198 of the Civil Code.

31 Kurka, Pař́ková, supra n. 24, at 150. See also Article 2 letter k) of the IA.

32 Cf. Article 3 par. 2 of Act no. 312/2006 Coll., on trustees in bankruptcy, as amended.

33 Cf. Article 97 par. 1 of the IA. 